\title{
DESENTRALISASI DAN PENGELOLAAN WILAYAH PESISIR DI INDONESIA STUDI PADA DESA KOHOD KECAMATAN PAKUHAJI KABUPATEN TANGERANG
}

\author{
Endiarjati Dewandaru Sadono \\ Magister Ekonomika Pembangunan \\ Fakultas Ekonomika dan Bisnis Universitas Gadjah Mada \\ Email: endiarjati.dewandaru@gmail.com
}

\begin{abstract}
The management of coastal areas in Indonesia has now been decentralized. This study tries to analyze qualitatively how the coastal area management has been done in Tangerang District, more precisely in Kohod Village, Pakuhaji Sub-District. Kohod Village became one of the three pilot projects village of Kampung Sejahtera conducted by Organisasi Aksi Solidaritas Era Kabinet Kerja (OASE Kabinet Kerja). Despite the considerable potential of coconut and laksa noodle development, but poverty, unemployment and slums are still the major problem in Kohod Village. Therefore, the development of coastal areas in this village can't be left entirely to the local community. It takes the role of the government and private sector to support the development acceleration in this village. Thus, the development of coastal areas in Kohod Village should be done using collaborative approach.
\end{abstract}

Keywords: Collaborative Coastal Management; Government; Local Community; Kohod.

\begin{abstract}
ABSTRAK
Pengelolaan wilayah pesisir di Indonesia saat ini sudah dilakukan secara desentralistik. Tulisan ini mencoba menganalisis secara kualitatif bagaimana pengelolaan wilayah pesisir yang selama ini dilakukan di Kabupaten Tangerang, lebih tepatnya di Desa Kohod, Kecamatan Pakuhaji. Desa Kohod menjadi salah satu dari tiga desa pilot project program Kampung Sejahtera yang dilakukan oleh Organisasi Aksi Solidaritas Era Kabinet Kerja (OASE Kabinet Kerja). Meskipun memiliki potensi kelapa dan pengembangan mie laksa yang cukup besar, tetapi kemiskinan, pengangguran, dan lingkungan yang kumuh masih menjadi permasalahan utama di Desa Kohod. Oleh karena itu, pengembangan wilayah pesisir di desa ini tidak dapat diserahkan sepenuhnya kepada masyarakat setempat. Dibutuhkan peran pemerintah dan swasta untuk mendukung percepatan pembangunan di sana. Dengan demikian, pengembangan wilayah pesisir di Desa Kohod harus dilakukan dengan menggunakan pendekatan kolaboratif.
\end{abstract}

Kata Kunci: Kohod; Masyarakat Setempat; Pemerintah; Pengelolaan Pesisir Kolaboratif. 


\section{PENGANTAR}

Indonesia adalah negara kepulauan yang terletak di antara benua Asia dan Australia serta di antara Samudera Hindia dan Pasifik. Negara ini terdiri dari sekitar 17.508 pulau, baik pulau besar maupun kecil. Jika ditarik garis lurus, maka panjang garis pantai di Indonesia mencapai $81.000 \mathrm{~km}$. Fitur geografis tersebut menjadi suatu tantangan bagi upaya perlindungan dan pelestarian lingkungan laut.

Laut Indonesia tidak dapat dipisahkan dari laut Asia Tenggara yang pada gilirannya merupakan bagian dari kepentingan laut global. Sudah bukan rahasia bahwa wilayah laut dan pesisir Asia Tenggara merupakan salah satu daerah yang paling produktif di dunia. Dikaruniai dengan iklim tropis, cuaca yang hangat dan lembab, serta curah hujan yang tinggi, menyebabkan terumbu karang yang luas dan ekosistem bakau yang lebat tumbuh subur di sepanjang garis pantai. Manfaat ekonomi yang berasal dari ekosistem yang kaya dan beragam ini, maka wilayah Asia Tenggara memiliki kepadatan penduduk yang tinggi. Lebih dari tujuh persen penduduk di wilayah tersebut tinggal di wilayah pesisir, sehingga tingkat eksploitasi sumber daya alam dan degradasi lingkungan cukup tinggi di wilayah tersebut. Selain itu, meningkatnya polusi dalam satu dekade terakhir memperparah masalah yang dihadapi oleh kawasan Asia Tenggara.

Eksistensi manusia tergantung pada ketersediaan sumber daya alam yang stabil dan berkelanjutan. Dengan demikian, ada nilai untuk menjaga lingkungan laut dan pesisir untuk mendukung pemanfaatan sumber daya kelautan secara berkelanjutan. Di sisi lain, penggunaan sumber daya laut secara berlebihan berdampak pada ketersediaan sumber daya dalam jangka panjang. Masalah pembangunan versus konservasi di wilayah ini meliputi: (1) penangkapan ikan berlebihan; (2) metode penangkapan ikan yang merusak; (3) kerusakan lingkungan; (4) konservasi spesies laut yang terancam punah; dan (5) pencemaran laut. Masalah-masalah tersebut tidak dapat diselesaikan pemerintah melalui sistem pemerintahan yang sentralistik. Pengelolaan wilayah pesisir di Indonesia saat ini sudah dilakukan secara desentralistik.

Kajian ini mencoba menganalisis secara kualitatif bagaimana pengelolaan wilayah pesisir yang selama ini dilakukan di Kabupaten Tangerang, lebih tepatnya di Desa Kohod, Kecamatan Pakuhaji. Desa Kohod menjadi salah satu dari tiga desa pilot project program Kampung Sejahtera yang dilakukan oleh Organisasi Aksi Solidaritas Era Kabinet Kerja (OASE Kabinet Kerja). OASE Kabinet Kerja merupakan sebuah kelompok yang beranggotakan ibu-ibu menteri di masa pemerintahan presiden Joko Widodo dengan ibu Iriana Joko Widodo sebagai ketuanya. Melihat desa ini sedang menjadi salah satu fokus pembangunan dan letaknya di wilayah pesisir, maka tentunya menarik untuk menganalisis bagaimana pengelolaan wilayah pesisir di sana.

Ada dua pendekatan dalam pengelolaan wilayah pesisir berbasis partisipasi dan pelibatan masyarakat, yaitu pengelolaan berbasis masyarakat (community-based management) dan pengelolaan kolaboratif (comanagement). Pengelolaan berbasis masyarakat adalah pengelolaan sumberdaya yang berfokus dan berpusat pada masyarakat, di mana masyarakat setempat bertanggung jawab terhadap pengambilan keputusan yang penting. Sementara itu, pengelolaan kolaboratif menekankan pada pengelolaan sumber daya yang berfokus pada masyarakat dengan lebih menjalin kerjasama dengan pemerintah atau pemangku kepentingan terkait dan masyarakat setempat sebagai struktur utama dalam manajemen (Siry, 2011). Jika pengelolaan berbasis masyarakat lebih bersifat pendekatan bottom-up, maka pengelolaan kolaboratif merupakan perpaduan pendekatan top-down dan bottom-up (Christie dan White, 1997).

Selain dua pendekatan tersebut, belum lama ini berkembang pengelolaan wilayah pesisir yang terintegrasi (Integrated Coastal Management). Pengelolaan wilayah pesisir yang terintegrasi mencakup ukuran manajemen yang berhubungan dengan timbal balik antara perubahan ekonomi, ekologis, sosial, alam, dan lingkungan yang memungkinkan 


\section{Endiarjati Dewandaru Sadono -- Desentralisasi dan Pengelolaan Wilayah Pesisir di Indonesia pada Desa Kohod Kecamatan Pakuhaji Kabupaten Tangerang}

masyarakat manusia yang mereka dukung tetap hidup berdampingan. Prinsip utamanya adalah keberlanjutan, perencanaan, dan pengelolaan partisipatif serta manajemen yang adaptif dan holistik. Pendekatan ini berfokus pada kerjasama, partisipasi, pengelolaan berbasis lokal, dan keterkaitan antarlembaga menegaskan hubungan yang saling melengkapi antara pengelolaan wilayah pesisir yang terintegrasi dan desentralisasi. Elemen penting dari pengelolaan wilayah pesisir yang terintegrasi adalah integrasi dan koordinasi pada berbagai level pemerintahan secara bersamaan, yang dapat mewadahi proses penilaian, perencanaan, dan implementasi yang dilakukan oleh pemerintah pusat ataupun pemerintah daerah melalui kerjasama dengan berbagai kelompok masyarakat (Wever et al., 2012). Pada dasarnya, pengelolaan kolaboratif hampir sama dengan pengelolaan wilayah pesisir yang terintegrasi dalam hal tujuan dan metode (Christie dan White, 1997).

Perencanaan dan proses pembangunan yang baik haruslah melibatkan masyarakat. Pendekatan top-down sendiri tidak akan menciptakan rasa memiliki di kalangan masyarakat. Sumberdaya dapat dilindungi dan dikelola secara berkelanjutan jika yang memanfaatkannya sehari-hari terlibat dalam perencanaan dan proses pembangunan. Sebagai contoh, Taman Laut Nasional di Kepulauan Seribu tidak melibatkan masyarakat sejak awal perencanaan, sehingga berbagai aturan yang diterapkan untuk melindungi sumberdaya yang ada di dalamnya banyak yang tidak ditaati oleh masyarakat (Fauzi dan Buchary, 2002). Sementara itu, Taman Laut Nasional Pulau Apo di Filipina merupakan contoh sukses di mana masyarakat terlibat sejak awal sehingga dalam pelaksanaannya mereka berkomitmen untuk mencapai target yang diinginkan (White et al., 2002).

Metode analisis ini bersifat kualitatif untuk menjelaskan pengelolaan wilayah pesisir di Desa Kohod, kecamatan Pakuhaji, Kabupaten Tangerang. Adapun data-data yang digunakan dalam penelitian ini ada yang bersumber dari dokumen perencanaan pemerintah Kabupaten Tangerang dan ada yang bersumber dari observasi lapangan. Observasi lapangan dilakukan oleh peneliti pada bulan September 2017. Peneliti juga berhasil mewawancarai beberapa perangkat desa, ketua BPD, ketua $\mathrm{RT}$, dan tokoh masyarakat untuk mendapatkan informasi yang mendalam mengenai kondisi sosial ekonomi terkini di sana.

\section{PEMBAHASAN \\ Kondisi Sosial-Ekonomi Desa Kohod}

Luas wilayah Desa Kohod yaitu 800 ha atau $80.000 \mathrm{~km}^{2}$ dengan jumlah penduduk sebanyak 8.755 jiwa. Adapun kepadatan penduduknya sebanyak $0,11 \mathrm{jiwa} / \mathrm{km}^{2}$. Dengan angka kepadatan seperti itu, maka dapat dikatakan bahwa kepadatan penduduk di Desa Kohod masih rendah. Berdasarkan letaknya, sebelah utara Desa Kohod berbatasan dengan Laut Jawa, sebelah selatan yaitu Desa Kalibaru, sebelah barat yaitu Desa Kramat, dan sebelah timur adalah Sungai Cisadane (Gambar 1).

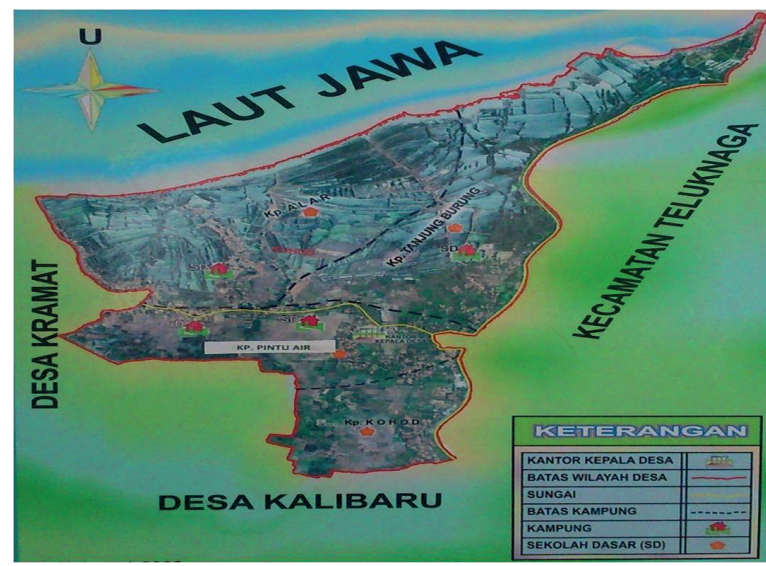

Gambar 1. Wilayah Desa Kohod

Sumber: Dokumentasi Pemerintah Desa Kohod

Secara administratif, Desa Kohod terbagi menjadi empat kampung antara lain: Kampung Kohod, Kampung Tanjung Burung, Kampung Pintu Air, dan Kampung Alar. Kampung yang memiliki luasan paling luas adalah Kampung Alar dengan luasan 350 hektar dan Kampung Pintu Air merupakan kampung dengan luasan terkecil (100 hektar). Meskipun demikian, Kampung Pintu Air merupakan pusat pemerintahan, di mana Kantor Desa dan Kantor BPD ada wilayah ini. Kampung Alar dan Tanjung Burung mayoritas lahannya 
berupa empang/tambak, sedangkan Kampung Kohod mayoritas lahannya berupa lahan pertanian/sawah.

Jumlah penduduk Desa Kohod pada tahun 2015 mencapai 8.755 Jiwa. Dari jumlah ini dapat diketahui bahwa jumlah penduduk laki-laki lebih banyak daripada penduduk perempuan. Penduduk laki-laki berjumlah 4.734 Jiwa, sedangkan penduduk perempuan berjumlah 4.021 Jiwa (lihat Tabel1). Dengan demikian, rasio jenis kelamin (sex ratio) penduduk Desa Kohod mencapai 117,73 persen. Dari tabel ini juga dapat diketahui bahwa rata-rata setiap keluarga di Desa Kohod beranggotakan empat orang. Angka tersebut diperoleh dari jumlah penduduk total dibagi dengan jumlah kepala keluarga $(4,22)$.

Selainitu, dari tabel inijuga dapatdiketahui bahwa rasio ketergantungan (dependency ratio) penduduk Desa Kohod mencapai 0,77. Artinya bahwa seorang penduduk usia produktif harus menanggung beban satu orang penduduk usia tidak produktif. Meskipun demikian, persentase penduduk miskin di Desa Kohod cukup tinggi, yaitu sebesar 41,7 persen. Dengan demikian, kemiskinan yang tinggi merupakan salah satu permasalahan yang harus segera diatasi agar Grand Design pembangunan Desa Kohod dapat direalisasikan oleh para pemangku kepentingan.

Tabel 1. Data Penduduk Desa Kohod, 2015

\begin{tabular}{l|l|l}
\hline No & \multicolumn{1}{|c|}{ Uraian } & \multicolumn{1}{|c}{ Jumlah } \\
\hline $\mathbf{1}$ & Laki - laki & 4.734 Jiwa \\
\hline $\mathbf{2}$ & Perempuan & 4.021 Jiwa \\
\hline $\mathbf{3}$ & Usia 0 - 15 tahun & 1.915 Jiwa \\
\hline $\mathbf{4}$ & Usia 16 - 65 Tahun & 4.955 Jiwa \\
\hline $\mathbf{5}$ & Usia 66 Tahun Keatas & 1.885 Jiwa \\
\hline $\mathbf{6}$ & Jumlah Penduduk Miskin & 3.650 Jiwa \\
\hline $\mathbf{7}$ & Jumlah KK & 2.074 KK \\
\hline
\end{tabular}

Sumber: Data Desa Kohod (2015)

Mata pencaharian penduduk Desa Kohod sebagian besar adalah petani, wiraswasta, dan nelayan (Tabel 2). Menariknya, jumlah penduduk tidak bekerja di Desa Kohod cukup banyak, yaitu mencapai 1.005 orang. Jumlah penduduk yang tidak bekerja mencapai 21,37 persen dari total penduduk yang bekerja. Angka pengangguran yang cukup tinggi tersebut juga menjadi permasalahan yang harus diselesaikan oleh para pemangku kepentingan. Programprogam dari para pemangku kepentingan harus diarahkan untuk menciptakan lapangan kerja. Terciptanya lapangan kerja yang banyak juga turut berkontribusi menurunkan angka kemiskinan.

Tabel 2. Mata Pencaharian Penduduk Desa Kohod, 2015

\begin{tabular}{|c|c|c|}
\hline No & Uraian & Jumlah \\
\hline 1 & Pegawai Negeri Sipil & 25 Orang \\
\hline 2 & TNI & 1 Orang \\
\hline 3 & Polri & 4 Orang \\
\hline 4 & Swasta & 500 Orang \\
\hline 5 & Wirawasta & 821 Orang \\
\hline 6 & Tani & 565 Orang \\
\hline 7 & Pertukangan & 87 Orang \\
\hline 8 & Buruh Tani & 1.015 Orang \\
\hline 9 & Pensiunan & 5 Orang \\
\hline 10 & Nelayan & 607 Orang \\
\hline 11 & Peternak & 50 Orang \\
\hline 12 & Jasa & 12 Orang \\
\hline 13 & Pengrajin & 5 Orang \\
\hline 14 & Tidak Bekerja & 1.005 Orang \\
\hline
\end{tabular}

Sumber: Data Desa Kohod (2015)

Fenomena loss generation pernah terjadi di Kabupaten Tangerang karena pada waktu itu Kabupaten Tangerang masih menjadi bagian dari Provinsi Jawa Barat. Akses pendidikan bagi penduduk usia sekitar 35 - 50 tahun pada waktu itu cukup jauh karena harus ke Bandung. Sebagian penduduk juga mengenyam pendidikan di DKI Jakarta, tetapi setelah Provinsi Banten terbentuk rata-rata penduduk sudah dapat bersekolah di Kabupaten Tangerang sendiri. Hal ini juga menjadi permasalahan karena tingkat pendidikan yang rendah dari generasi sebelumnya tentu menyebabkan generasi penduduk sekarang juga rendah. Oleh karena itu, perlu diidentifikasi berapa banyak penduduk usia sekitar 35 - 50 tahun yang pendidikannya rendah sehingga memudahkan pelaksanaan program-program bidang pendidikan yang telah direncanakan. 


\section{Endiarjati Dewandaru Sadono -- Desentralisasi dan Pengelolaan Wilayah Pesisir di Indonesia pada Desa Kohod Kecamatan Pakuhaji Kabupaten Tangerang}

\section{Potensi dan Kondisi Lingkungan di Desa Kohod}

Komoditas kelapa menjadi salah satu komoditas yang potensial dikembangkan di Desa Kohod. Lahan untuk perkebunan kelapa di Desa Kohod dapat dibedakan menjadi dua berdasarkan kepemilikannya, yaitu milik Perhutani dan masyarakat setempat. Lahan milik Perhutani mayoritas ada di Kampung Alar, berdekatan dengan Hutan Mangrove yang ada di pesisir pantai. Sementara itu, lahan milik masyarakat setempat mayoritas ada di Kampung Pintu Air dan Kampung Tanjung Burung (Gambar 2 dan Gambar 3).

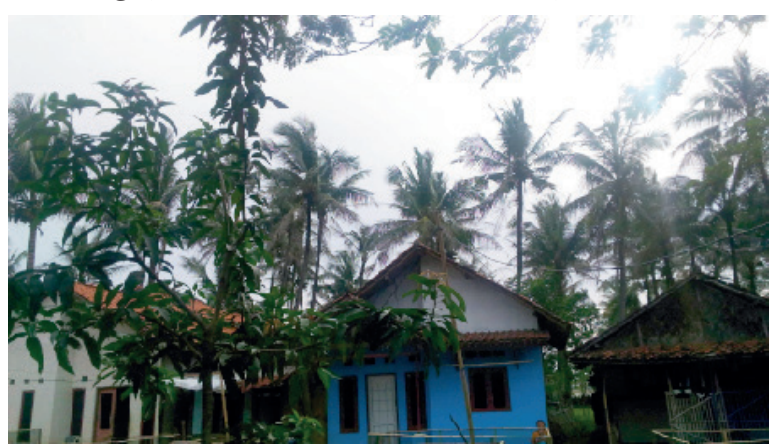

Gambar 2. Kondisi Tanaman Kelapa di Kampung Pintu Air

Sumber: Dokumen Pribadi Kunjungan Lapangan (2017)

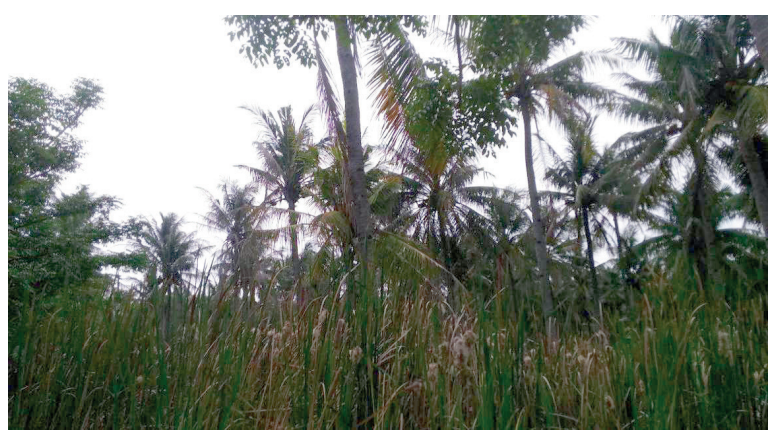

Gambar 3. Kondisi Tanaman Kelapa di Kampung Tanjung Burung

Sumber: Dokumen Pribadi Kunjungan Lapangan (2017)

Selain sebagai penghasil kelapa, Desa Kohod juga merupakan salah satu penghasil laksa (mie putih dari beras IR64) terbesar di Kabupaten Tangerang. Laksa biasanya dimakan dengan ayam panggang dan kuah santan.
Produksi laksa di Desa ini sudah dilakukan secara turun-temurun. Masyarakat berharap produksi laksa dapat terus dilestarikan karena memberikan manfaat ekonomi yang besar dan sudah mampu dijual di Taman Kota.

Sementara itu, lingkungan alam di Desa Kohod cenderung kumuh. Gambar 4 berikut menunjukkan kondisi pantai di Kampung Alar yang sangat kumuh, bahkan dipenuhi sampah dari laut. Pantai ini sudah mengalami abrasi sejauh 1 kilometer dari garis pantai yang sebelumnya meskipun di dekat pantai tersebut ada hutan mangrove milik PT. Perhutani. Keberadaan Hutan Mangrove ternyata tidak cukup menahan abrasi, sehingga diperlukan tanggul dari beton agar mampu menahan abrasi. Abrasi yang terjadi merupakan akumulasi sampah dan bahan kimia berbahaya dariSungai Cisadane dan beberapa sungai besar di Jakarta (Nur et al., 2001). Abrasi seperti ini tentunya tidak baik bagi masyarakat di sekitar pantai dan dapat mengancam pertanaman kelapa yang agak masuk ke dalam (kurang lebih radius 1 kilometer dari garis pantai yang sekarang).

Tidak adanya tempat pembuangan akhir menjadi masalah dalam pengelolaan sampah di Desa Kohod. Seperti ditunjukkan pada Gambar 5, masyarakat Desa Kohod selama ini bergotong-royong membersihkan sampah dan mengumpulkannya di satu tempat, yaitu di Kampung Pintu Air. Adanya tong sampah yang disediakan secara swadaya oleh masyarakat (Gambar 6a) ternyata masih belum cukup untuk mengatasi permasalahan sampah di Desa ini. Selain itu, ketersediaan infrastruktur di Desa ini masih sangat kurang. Seperti pada Gambar 6b, jalan penghubung antarempang hanya berupa kayu. Padahal jalan tersebut sering digunakan masyarakat untuk mengangkut hasil panen buah kelapa dan ikan-ikan mereka dari empang. Tidak adanya lampu penerangan jalan di jalan utama Desa Kohod juga membuat masyarakat berinisiatif untuk membuat marka sendiri secara swadaya (Gambar 7). Masyarakat berinisiatif mengecat pohon dan jalan utama agar di malam hari memudahkan pengendara mobil/motor untuk lewat di jalan tersebut. 


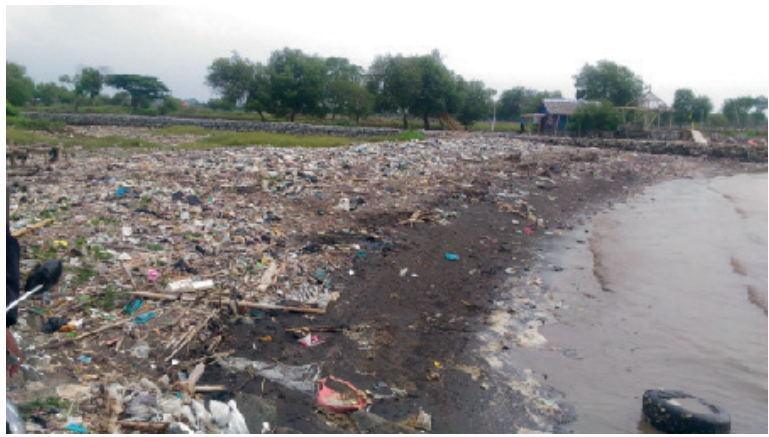

Gambar 4. Kondisi Pantai di Kampung Alar yang Kumuh

Sumber: Dokumen Pribadi Kunjungan Lapangan (2017)

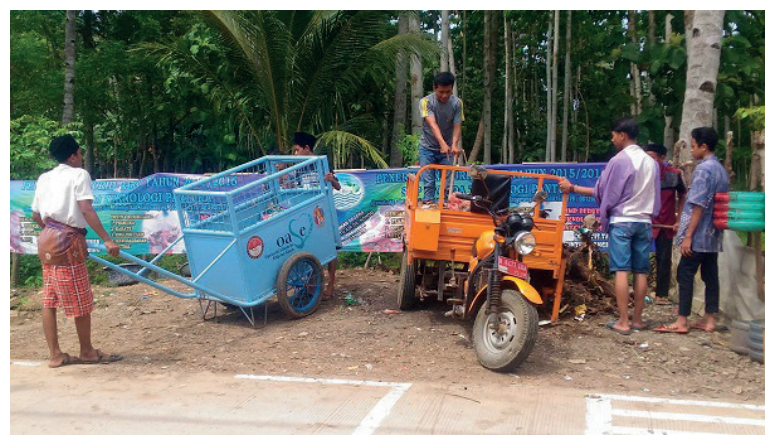

Gambar 5. Masyarakat Bergotong Royong Membersihkan Sampah

Sumber: Dokumen Pribadi Kunjungan Lapangan (2017)

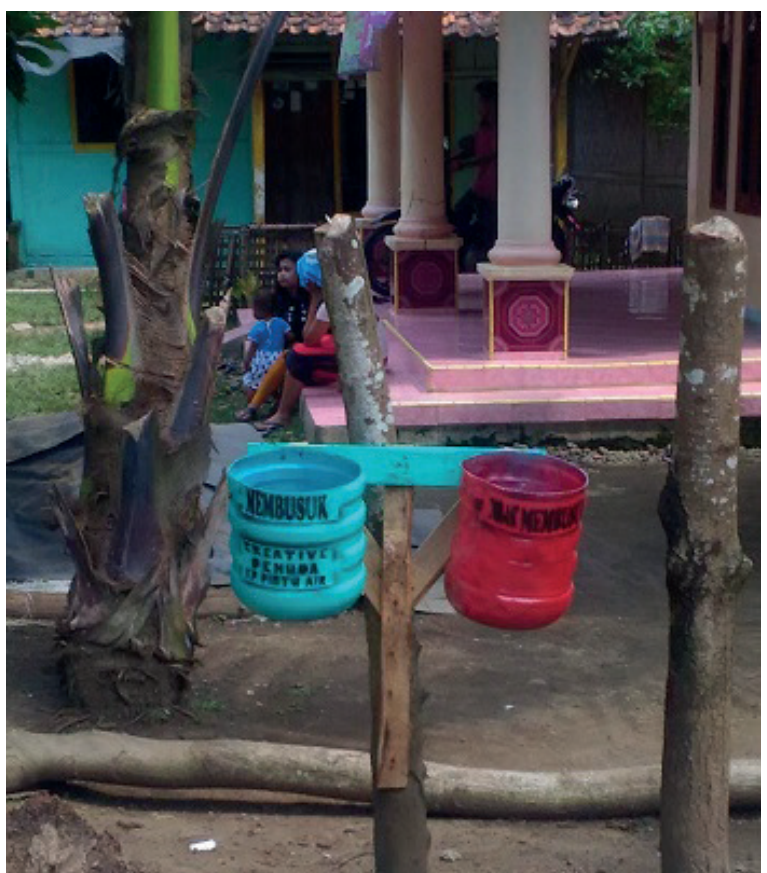

(a)

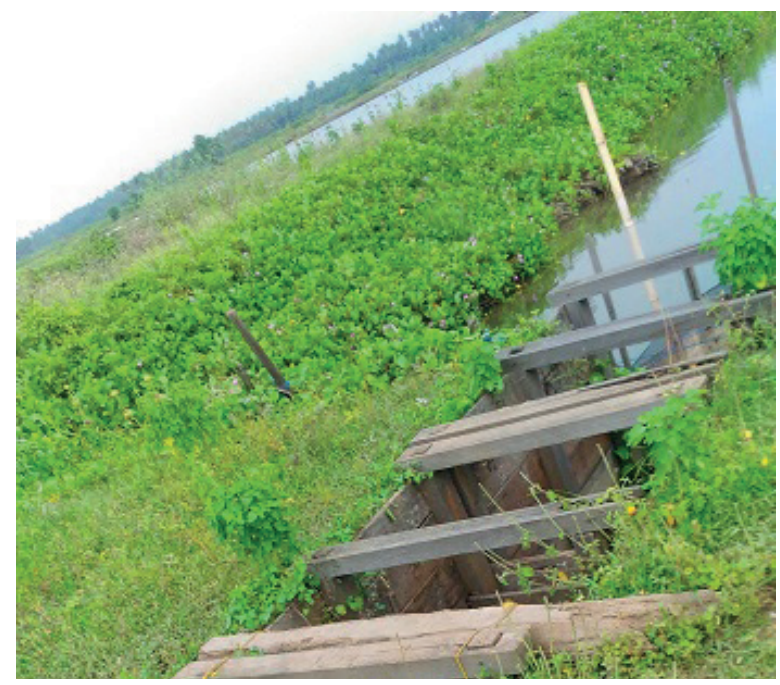

(b)

Gambar 6. Tong Sampah dan Jalan Penghubung antar Empang yang Terdapat di Desa Kohod Sumber: Dokumen Pribadi Kunjungan Lapangan (2017)

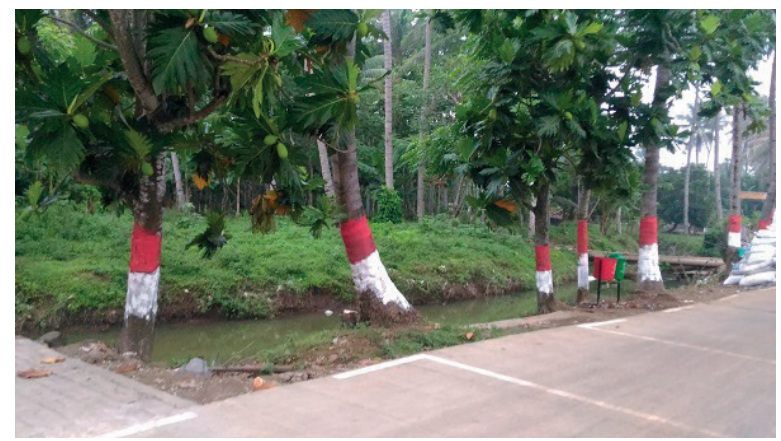

Gambar 7. Kondisi Jalan Utama di Desa Kohod Sumber: Dokumen Pribadi Kunjungan Lapangan (2017)

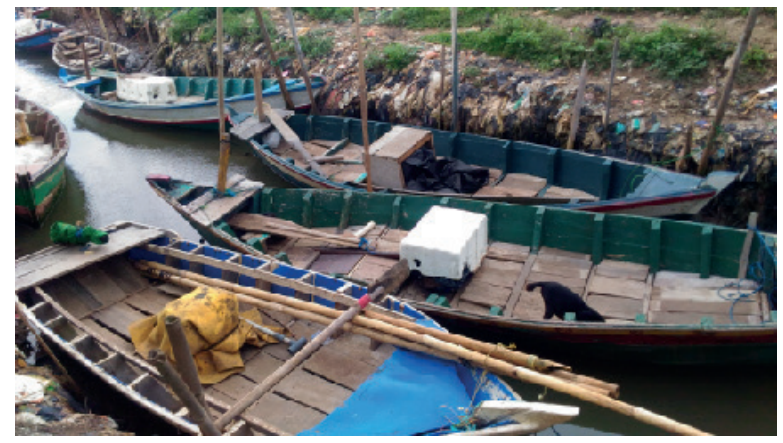

Gambar 8. Kondisi Perairan di Kampung Tanjung Burung yang Kumuh Sumber: Dokumen Pribadi Kunjungan Lapangan (2017) 
Gambar 8 menunjukkan kondisi perairan di Kampung Tanjung Burung yang kumuh. Tempat tersebut digunakan nelayan setempat untuk berlabuh. Kapal-kapal yang digunakan nelayan pun masih berupa kapal mesin sederhana yang hanya mampu menyisir ikan di sekitaran garis pantai. Kapal-kapal tersebut tidak dapat digunakan nelayan untuk melaut agak ke tengah. Jika Pemerintah dan masyarakat ingin membuat agar nelayan dapat melaut agak ke tengah, maka diperlukan kapal mesin yang kapasitas tangkapannya lebih besar. Itupun harus membangun dermaga terlebih dahulu karena pinggiran pantainya dangkal sehingga kapal mesin besar tidak dapat berlabuh. Pekerjaan menjadi nelayan merupakan opsi alternatif bagi masyarakat Desa Kohod selain dari pertanaman kelapa. Apalagi di Desa Kohod sudah ada beberapa kelompok nelayan. Mengingat tingkat kemiskinan dan tingkat pengangguran cukup tinggi di Desa ini, membuka lapangan kerja lain dapat menjadi solusi untuk mengurangi kemiskinan dan pengangguran tersebut.

\section{Skema Pengembangan Desa Kohod}

Kemiskinan, pengangguran, dan lingkungan yang kumuh masih menjadi permasalahan utama di Desa Kohod. Oleh karena itu, pengembangan wilayah pesisir di desa ini tidak dapat diserahkan sepenuhnya kepada masyarakat setempat. Dibutuhkan peran pemerintah dan swasta untuk mendukung percepatan pembangunan. Dengan demikian, pengembangan wilayah pesisir di Desa Kohod harus dilakukan dengan menggunakan pendekatan kolaboratif.

Perekonomian Desa Kohod diharapkan dapat dikembangkan secara sinergis antara pemerintah (top-down) dan masyarakat (bottomup). Dari sisi pemerintah, para pemangku kepentingan yang terlibat adalah kementerian/ lembaga, dinas, bupati, dan camat. Sementara dari sisi masyarakat, para pemangku kepentingan yang terlibat adalah kepala desa, Badan Permusyawaratan Desa (BPD), Rukun Warga (RW), Rukun Tetangga (RT), dan masyarakat sendiri. Kerjasama yang sinergis antara Pemerintah dan masyarakat harus memperhatikan potensi pasar, sumberdaya manusia, dan sumberdaya alam yang tersedia. Potensi sumberdaya alam di Desa Kohod cukup banyak dan pasarnya juga ada. Akan tetapi, kualitas sumberdaya manusia penduduk Desa Kohod masih rendah. Untuk itu, peran pihak swasta adalah membantu pemerintah dan masyarakat dalam meningkatkan nilai tambah produk kelapa Desa Kohod agar mampu bersaing di pasar (Gambar 9).

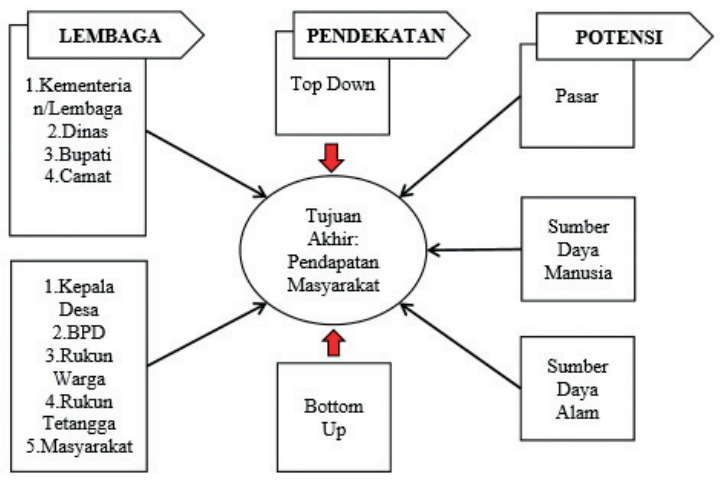

Gambar 9. Skema Pengembangan Desa Kohod

Permasalahahan kerjasama antara masyarakat Desa Kohod dan Pemerintah dapat dijelaskan dengan menggunakan pendekatan mikroekonomi seperti pada Gambar 10. Pemerintah berperan dari sisi penawaran, di mana mereka berusaha menyediakan sejumlah layanan tertentu dengan harga yang serendah mungkin karena mereka menghadapi kendala anggaran (APBD). Sementara itu, masyarakat berperan dari sisi permintaan, di mana mereka berusaha mendapatkan sejumlah layanan tertentu dengan harga yang terjangkau karena kendala pendapatan mereka. Akan tetapi, interaksi antara pemerintah dan masyarakat terkadang sulit menemui titik temu (equilibrium). Hal ini terjadi karena pemerintah dan masyarakat sama-sama ingin memaksimalkan utilitas (maximize utility), tetapi dengan kendala yang mereka hadapi (subject to constraints). Secara umum, kendala yang dihadapi Pemerintah Kabupaten Tangerang adalah administrasi yang rumit dan koordinasi yang buruk dengan pemerintah pusat. Sementara itu, kendala yang dihadapi masyarakat Desa Kohod adalah 
belum ada koperasi atau BUMDes, kualitas sumberdaya manusia rendah, persentase penduduk miskin cukup tinggi, lingkungan kumuh, dan kurangnya pelembagaan UU Desa. Permasalahan tersebut menghambat pihak swasta untuk masuk.

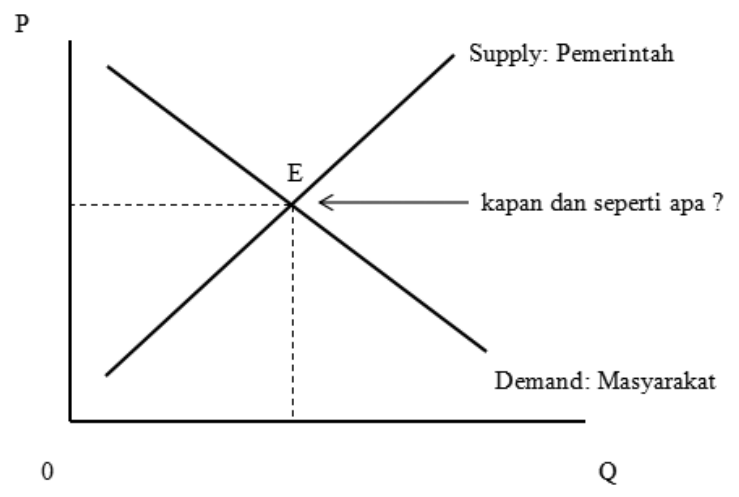

Gambar 10. Kerangka Mikroekonomi Permasalahan Kerjasama MasyarakatPemerintah

Permasalahan mendasar di tingkat Pemerintah Kabupaten Tangerang menyebabkan kebingungan tersendiri. Bantuan program dari kementerian/lembaga tertentu terkadang terlambat sampai ke Desa Kohod karena tidak jelasnya administrasi program antara kementerian/lembaga tersebut dan Pemerintah Kabupaten Tangerang. Koordinasi dengan pihak Kecamatan Pakuhaji dan Desa Kohod juga tidak terlalu mulus. Hal ini salah satunya disebabkan oleh kurangnya pelembagaan UU Desa. Di lingkungan Desa Kohod sendiri, koordinasi antara Kepala Desa Kohod dengan Ketua BPD juga tidak terlalu mulus. Sebagai contoh, dalam kasus musyawarah desa untuk membahas RPJMDes, kepala desa kurang kooperatif dengan Ketua BPD sehingga hasil yang disepakati dalam RPJMDes belum dapat- diterapkan dengan baik. Kasus ini hampir sama dengan pengelolaan wilayah pesisir di Kecamatan Likupang, Kabupaten Minahasa, Provinsi Sumatera Utara (Crawford dkk., 2006).

\section{Skema Pemantauan dan Evaluasi}

Gambar 11 berikut menunjukkan kerangka berpikir untuk melakukan pemantauan dan evaluasi dampak sosial, ekonomi, dan lingkungan atas suatu proses pembangunan. Secara garis besar, kerangka berpikir ini berbentuk seperti donat, di mana di dalam lingkaran berwarna hijau inilah kondisi ideal bagi manusia untuk hidup. Di dalam lingkaran inilah pembangunan ekonomi inklusif dan berkelanjutan dapat dilakukan. Daerah di bagian dalam lingkaran hijau adalah fondasi sosial, sedangkan daerah di luar lingkaran hijau adalah batasan lingkungan (Ratworth, 2012).

Fondasi sosial yang dimaksud adalah hakhak dasar yang harus dipernuhi agar manusia dapat hidup dengan layak. Apabila kebutuhan dasar manusia tidak terpenuhi, maka tingkat pengangguran dan kemiskinan akan sangat tinggi. Sementara itu yang dimaksud batasan lingkungan adalah apabila manusia sudah dapat memenuhi kebutuhan hidupnya secara berlebihan maka dia akan cenderung serakah sehingga dapat menyebabkan kerusakan lingkungan. Kerusakan lingkungan inilah yang akan mengancam kehidupan manusia sehingga pembangunan tidak dapat berkelanjutan.

Ratworth (2012) juga mengemukakan indikator-indikator yang dapat digunakan untuk mengukur fondasi sosial dan batasan lingkungan. Indikator yang bisa mengukur fondasi sosial antara lain: akses terhadap makanan, akses terhadap minuman, akses terhadap pendapatan, akses terhadap pendidikan, hak untuk memperoleh pertahanan dan keamanan, kebebasan berpendapat, akses terhadap pekerjaan, akses terhadap energi, persamaan sosial, kesetaraan gender, dan akses terhadap kesehatan.

Sementara itu, indikator yang dapat mengukur batasan lingkungan antara lain: penggunaan air bersih, siklus nitrogen dan fosfor, pengasaman laut, polusi kimia, muatan aerosol atmosfer, kerusakan lapisan ozon, hilangnya keanekaragaman hayati, alih fungsi lahan, dan perubahan iklim.

Dalam konteks pengembangan wilayah pesisir di Desa Kohod, setiap warganya harus diarahkan untuk dapat memenuhi kebutuhan hidup minimalnya sehingga dapat berada di lingkaran warna hijau. Dengan demikian, tidak 


\section{Endiarjati Dewandaru Sadono -- Desentralisasi dan Pengelolaan Wilayah Pesisir di Indonesia pada Desa Kohod Kecamatan Pakuhaji Kabupaten Tangerang}

ada masyarakat yang miskin dan menganggur. Akan tetapi, pembangunan yang dilakukan terhadap mereka tidak boleh melebihi batasan luar lingkaran hijau tersebut. Dengan kata lain, jangan sampai menimbulkan kerusakan lingkungan.

Perubahan-perubahan yang terjadi di Desa Kohod dapat diukur dengan menggunakan indikator fondasi sosial dan batasan lingkungan seperti yang telah disebutkan sebelumnya. Perubahan-perubahan tersebut harus senantiasa dipantau dan dievaluasi paling tidak setiap tahun sekali. Hasil pemantauan dan evaluasi tersebut adalah basis data. Basis data tersebut dapat digunakan untuk merumuskan kebijakan terkait pengembangan wilayah pesisir di Desa Kohod.

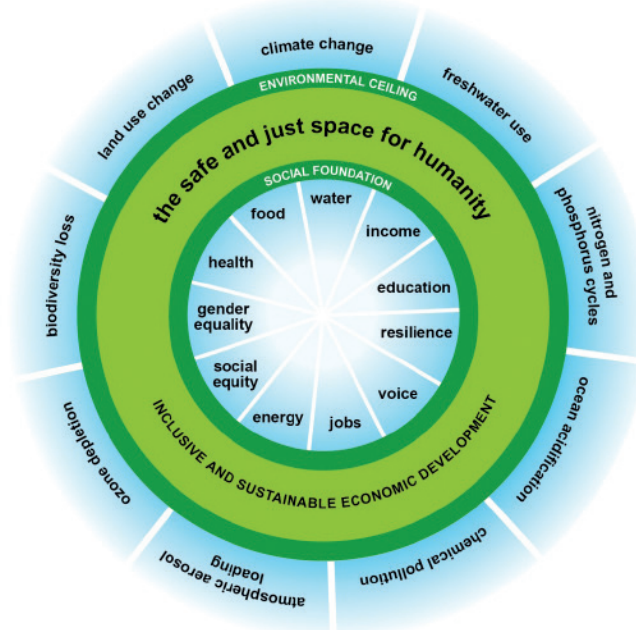

Gambar 11. A safe and just space for humanity framework

Sumber: Ratworth (2012)

Suatu basis data tentunya dibangun dari indikator-indikator tertentu. Indikatorindikator yang dapat digunakan untuk memantau dan mengevaluasi pengembangan wilayah pesisir di Desa Kohod berdasarkan kerangka pikir yang dikemukakan oleh Ratworth (2012) adalah pendapatan masyarakat, angka harapan hidup, tingkat pendidikan, tingkat kesehatan, indeks kebahagiaan, indeks demokrasi, indeks pembangunan manusia, tingkat kemiskinan, tingkat pengangguran, ketersediaan air bersih dan air minum, dan tingkat alih fungsi lahan.

\section{SIMPULAN}

Meskipun memiliki potensi kelapa dan pengembangan mie laksa yang cukup besar, tetapi kemiskinan, pengangguran, dan lingkungan yang kumuh masih menjadi permasalahan utama di Desa Kohod. Oleh karena itu, pengembangan wilayah pesisir di desa ini tidak dapat diserahkan sepenuhnya kepada masyarakat setempat. Dibutuhkan peran pemerintah dan swasta untuk mendukung percepatan pembangunan di Desa Kohod. Dengan demikian, pengembangan wilayah pesisir di Desa Kohod harus dilakukan dengan menggunakan pendekatan kolaboratif agar pengembangan wilayah pesisir di Desa Kohod dapat senantiasa dipantau dan dievaluasi. Untuk itu, ada beberapa indikator menurut kerangka pikir yang dikemukakan Ratworth (2012) yang dapat digunakan. Indikator-indikator tersebut antara lain: (1) pendapatan masyarakat; (2) angka harapan hidup; (3) tingkat pendidikan; (4) tingkat kesehatan; (5) indeks kebahagiaan; (6) indeks demokrasi; (7) indeks pembangunan manusia; (8) tingkat kemiskinan; (9) tingkat pengangguran; (10) ketersediaan air bersih dan air minum; serta (11) tingkat alih fungsi lahan.

\section{DAFTAR PUSTAKA}

Christie, P., A. T. White. 1997. "Trends in development of coastal area management in tropical countries: From central to community orientation", Coastal Management, Vol. 25: 155-181.

Crawford, B., et al. 2006. “Factors Influencing Progress in Establishing CommunityBased Marine Protected Areas in Indonesia", Coastal Management, Vol. 34: 39-64.

Fauzi, A., E. A. Buchary. 2002. " A Socioeconomic Perspective of Environmental Degradation at Kepulauan Seribu Marine National Park, Indonesia", Coastal Management, Vol. 30: 167-181.

Nur, Y., et al. 2001. "Towards wise coastal management practice in a tropical 
megacity - Jakarta", Ocean \& Coastal Management, Vol. 44: 335-353.

Ratworth, K. 2012. A Safe and Just Space for Humanity: Can we live within the Doughnut?" Oxfam Discussion Paper, February 2012.

Siry, H. Y. 2011. "In search of appropriate approaches to coastal zone management in Indonesia", Ocean $\mathcal{E}$ Coastal Management, Vol. 54: 469-477.
Wever, L., et al. 2012. "Decentralization and participation in integrated coastal management", Ocean \& Coastal Management, Vol. 66: 63-72.

White, A. T., C. A. Courtney, and A. Salamanca. 2002. "Experience with Marine Protected Area Planning and Management in the Phillipines", Coastal Management, Vol. 30: 1-26. 